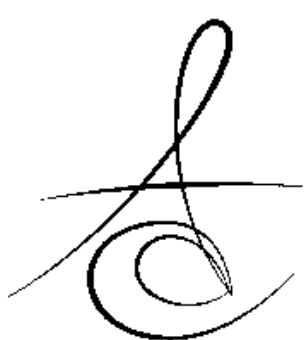

Makale Kodu/Article code: 1254

Makale Gönderilme tarihi: 05.08 .2013

Kabul Tarihi: 21.10.2013

\section{MIGRATION OF DENTAL IMPLANTS INTO MAXILLARY SINUS DURING THE HEALING PERIOD DUE TO WRONG INDICATION: REPORT OF 2 CASES}

\author{
YANLIŞ ENDİKASYONA BAĞLI OLARAK İYİLEŞME SÜRECİNDE MAKSİLLER \\ SİNÜSE DENTAL İMPLANTLARIN MİGRASYONU: 2 VAKA RAPORU
}

\author{
Dr. Cem ÜNGÖR* Dr. Kerem Turgut ATASOY*
}

Dr. Figen ÇİZMECi ŞENEL*

\section{ABSTRACT}

Displacement of dental implants into the maxillary sinus and related anatomic structures is a rare, but increasingly reported complication. Diagnosis of the affected structures related with maxillary sinus and determining the exact position of the dental implant are essential before the removal procedure of the migrated dental implant. After a clinical and radiological examination, an indicated procedure for every case should be decided. In this presented clinical case reports, migrated dental implants into the maxillary sinus cavity in the healing period and the management of this complication were described.

Key Words: Sinus augmention, dental implants, displacement, maxillary sinus, Caldwell-Luc

\section{ÖZET}

Dental implatların, maksiler sinüs ya da bağlantılı anatomik yapılara deplase olması oldukça nadirdir fakat bu komplikasyon ile ilgili raporlar artmaktadır. Deplase implantın çıkarılma işleminden önce, maksiler sinüs ve etkilenen dokuların diagnozu ve implantın kesin pozisyonunun belirlenmesi oldukça önemlidir. Yapılan klinik ve radyolojik muayeneden sonra ilgili vaka için uygun cerrahi prosedüre karar verilmelidir. Sunulan klinik vaka raporlarında, iyileşme döneminde maksiler sinüse deplase olan dental implantlar ve bu komplikasyonun tedavisi anlatılmaktadır.

Key Words: Sinüs ogmentasyonu, dental implantlar, deplasman, maksiler sinüs, Caldwell-Luc

\section{INTRODUCTION}

Implant-supported restorations provide a peerless option for rehabilitation of edentulous posterior maxilla. Insufficient bone height related to progressive resorption of the alveolar ridge and further pneumatization of the maxillary sinus may contraindicate conventional implant placement. Sinus lifting procedure have allowed implants to be placed in atrophic maxillas with high success rates. ${ }^{1}$ Alternative tecniques such as tilted implants, zygomatic implants, pterygoid implants, short and mini implants, restorations in cantilever or even graftless sinus flor elevation have been described as suitable methods to restore posterior occlusal function with implantsupported prostheses. ${ }^{2,3}$
In literature, there are clinical reports deal with displacement of dental implants into the maxillary, ethmoid and sphenoid sinus, nose and cranial fossa. ${ }^{4-7}$ The placement of implants without an adequate primary stability, the alterations of the intrasinusal and nasal pressures, autoimmune reaction to the implant or incorrect distribution of occlusal forces may lead this unfavorable situation. ${ }^{8,9}$ Displacement of dental implants into the maxillary sinus can cause complications such as maxillary sinusitis, pain and infection of surrounding tissues. Furthermore this complications require correct management and if this surgical complications are not treated adequately, the implant can migrate to upper craniofacial structures causing major complications. ${ }^{8}$ Different treatment options have used to deal with this

* Karadeniz Technical University Faculty of Dentistry Department of Oral and Maxillofacial Surgery 
Atatürk Üniv. Diş Hek. Fak. Derg.

J Dent Fac Atatürk Uni

Cilt:24, Sayı:1, Yıl: 2014, Sayfa: 93-97

complication, from a conservative approach (i.e. leave the migrated implant untreated under monitoring) to endoscopic transnasal procedures or a conventional Caldwell-Luc technique. ${ }^{2}$

In this clinical case report, two cases of dental implant migration into maxillary sinus during the healing period due to wrong diagnosis and the surgical treatment of these complications were presented.

\section{CASE REPORT 1}

A 39 year-old woman with no systemic disease and maxillary sinus patology was referred to Karadeniz Technical University, Faculty of Dentistry, Department of Oral and Maxillofacial Surgery for dental implant treatment. Her maxilla was edentulous while her mandible was partially edentulous (Figure 1). The residual bone height was approximately $2 \mathrm{~mm}$ on her left maxillary posterior region which was planned for sinus lifting procedure with dental implant placement. The patient was treated with unilateral sinus lifting procedure following 6 implant (Osseolink dental implant system, Bedford, Massachusetts, USA) placement into her maxilla. Lateral wall technique was performed for sinus lifting procedure and Demineralized Bone Matrix (DBM) was used as a graft material. After 2 months from the first operation, 6 implants were placed into her mandible. The follow-up sessions were performed on post-operative 1st, 3rd and 6th months clinically and radiographically. Clinical and radiographic examination was uneventful at 1st and 3rd month controls (Figure-2,3). On the 6th month radiographic examination, panoramic radiography has shown that the implant placed at left upper second molar area was migrated into the left maxillary sinus (Figure-4). Cone-beam tomography showed the implant at level of ostium in right maxillary sinus (Figure-5). The intraoral examination showed no inflammatory reaction such as an oroantral fistula. The patient had no symptom and she was informed about the requirement for the removal of the migrated implant. The patient accepted the implant removal procedure however she refused further grafting and implant placement procedures. The implant was removed from the left maxillary sinus under deep sedation. An intraoral approach via Caldwell-Luc technique was achieved and the dental
ÜNGÖR, ATASOY, ÇİZMECİ ŞENEL

implant was found attached to the sinus membrane and there were no inflammatory changes (Figure-6). The patient recovered well with no evidence of sinus infection.

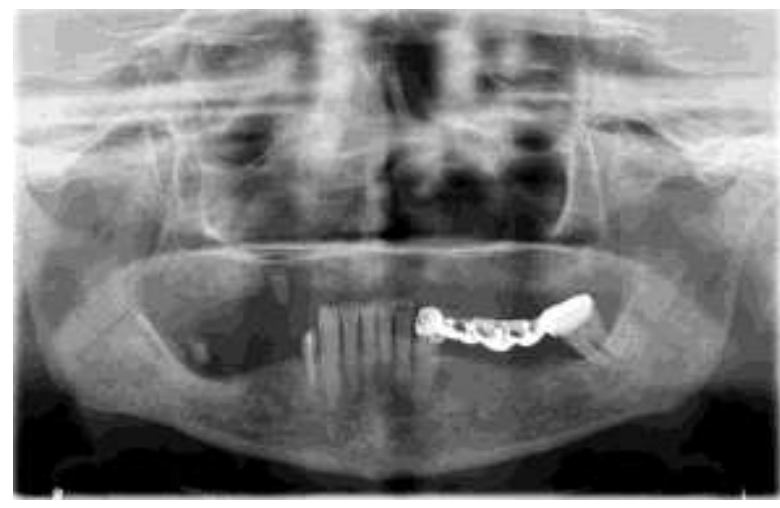

Figure 1 . The preoperative panaromic radiography of the case 1

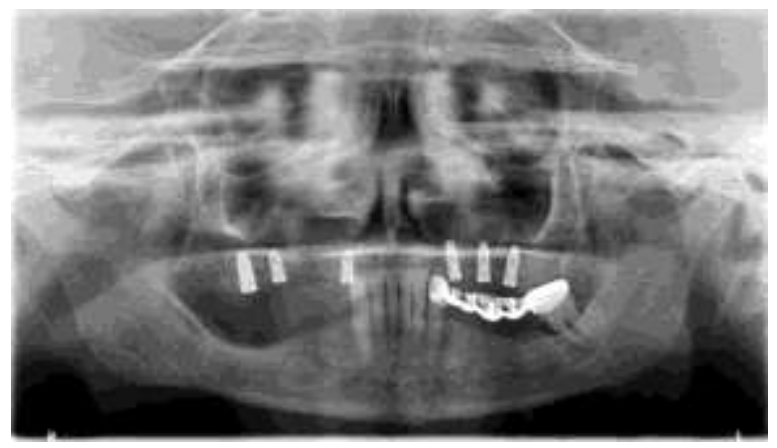

Figure 2 . The control radiography at 1 -month of the case 1

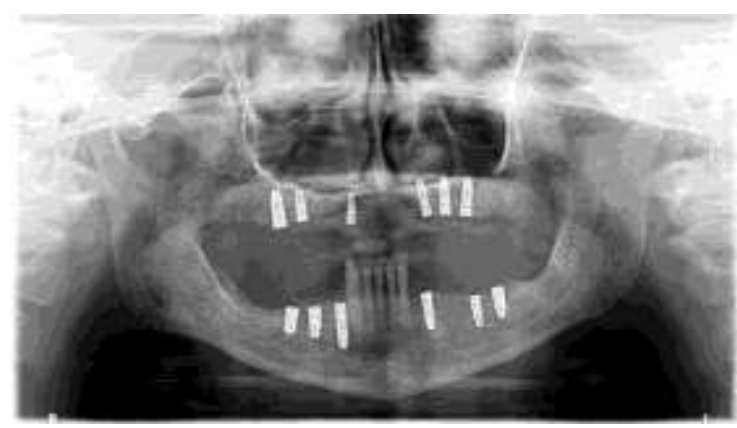

Figure 3. The control radiography at 3-month of the case 1

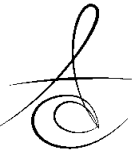


Atatürk Üniv. Diş Hek. Fak. Derg.

] Dent Fac Atatürk Uni

Cilt:24, Sayı:1, Yıl: 2014, Sayfa: 93-97

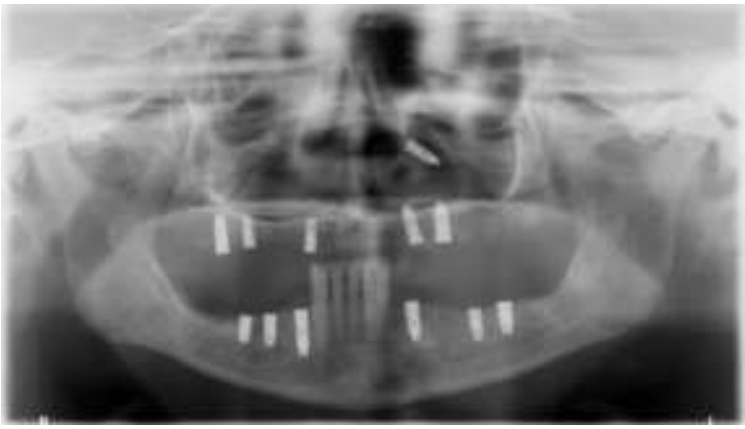

Figure 4. The radiographic view of the displaced implant at case 1

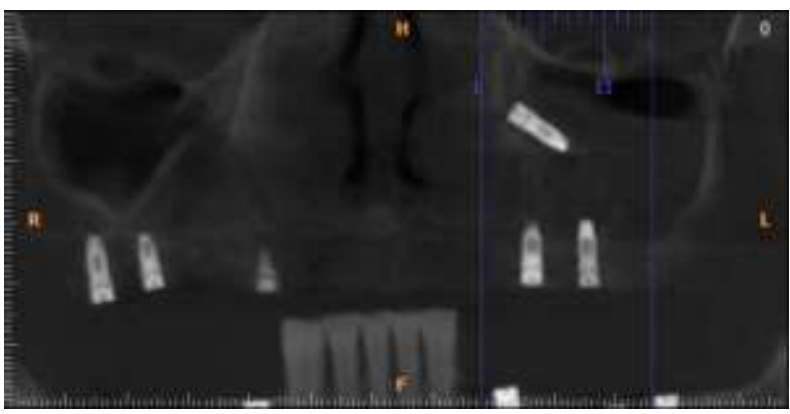

Figure 5. The computed tomography view of the displaced implant at case 1

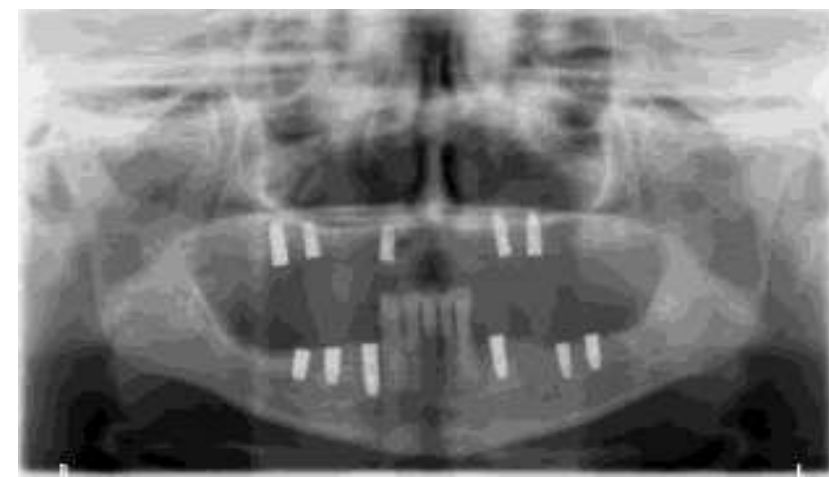

Figure 6 . The postoperative panaromic radiography of the case-1
ÜNGÖR, ATASOY,

ÇIZMECI ŞENEL

\section{CASE REPORT 2}

A 59 year-old woman with no systemic disease and maxillary sinus patology was evaluated in Karadeniz Technical University, Faculty of Dentistry, Department of Oral and Maxillofacial Surgery for dental implant rehabilitation. She had no posterior maxillary teeth and five dental implants (Osseolink dental implant system, Bedford, Massachusetts, USA) were decided to be placed along with unilateral sinus lifting procedure on right maxillary sinus (Figure-7). Lateral wall technique was performed for sinus lifting procedure and DBM was applied as a graft material. The post-operative controls were done by clinical and radiological examination on 1st, 3rd and 8th months. 1st and 3rd month controls were uneventful (Figure8). On the 8th month control, radiographical examination revealed that one of the implants were migrated into the maxillary sinus while the patient had no complaints or evidence of sinus infection (Figure9). The migrated implant was removed under local anesthesia via Caldwell-Luc approach. The patient was informed for the requirement of bone grafting and placement of a new implant procedures. One implant were placed anteriorly to explanted implant site and recovered uneventfully.

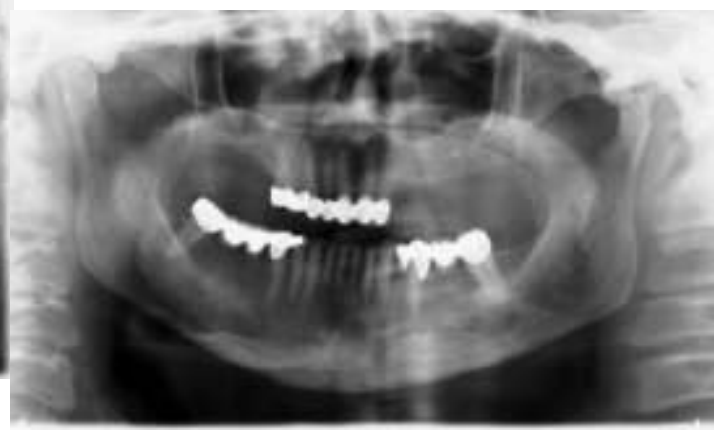

Figure 7. The preoperative panaromic radiography of the case 2 


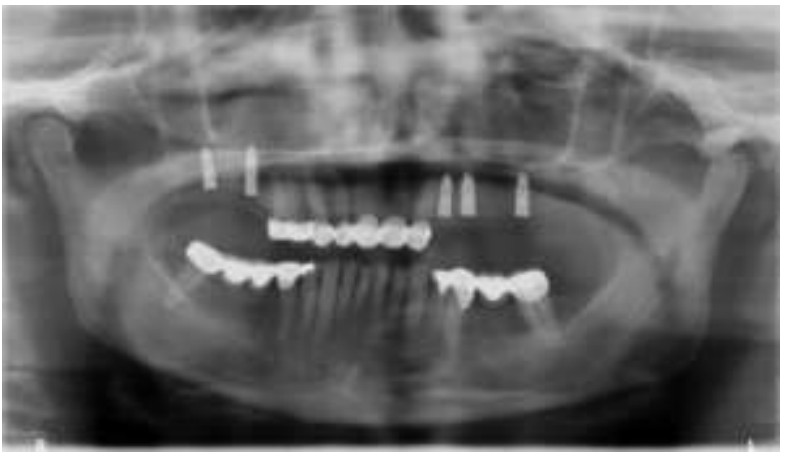

Figure 8 . The control radiography at 3-month of the case 2

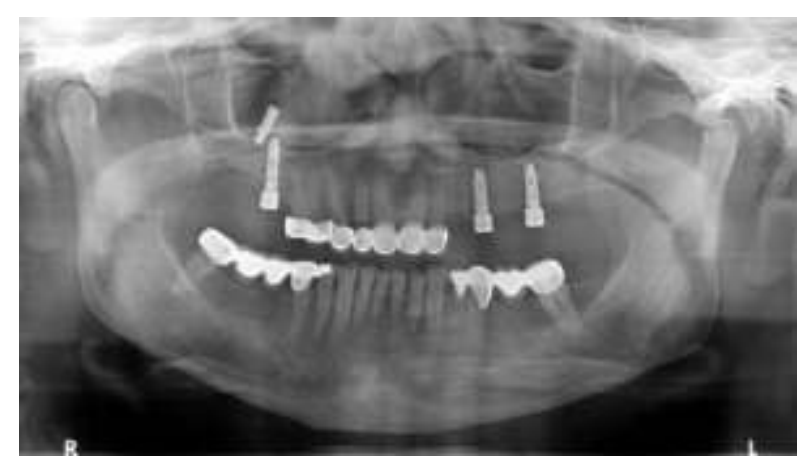

Figure 9. The radiographic view of the displaced implant at case 2

\section{DISCUSSION}

Dental implant treatment is the gold standart for rehabilitation of tooth loss and can be successfully performed along with sinus lifting procedure especially in cases of maxillary sinus pneumatization at posterior maxillary region. The procedure leads to unique complications such as sinusitis, rhinorhoea, oroantral fistulas and foreign body reactions. ${ }^{6}$

In literature, there are few reports of the displacement of dental implants into the maxillary sinus and the other associated anatomical structures during the healing period. ${ }^{2,10,11}$ In these present cases, the migration of the dental implants into the maxillary sinus occured in healing process without any pain and infection sympthom. This situation was detected in routine radiographic examination. The reason that leads to the migration is unknown. The possible mechanisms that could explain this complication were the presence of sinusitis before the procedure, poor primary stability of the implant and the alterations of the intrasinusal and nasal pressures. Iida et $\mathrm{al}^{5}$ reported a rare case of a displaced dental implant into the maxillary sinus after 5 years protetic loading. Improper prosthetic restorations might be associated with displacement of dental implant into the maxillary sinus due to incorrect distribution of occlusal forces. In this report, presence of insufficient residuel bone and poor primary stability of the inserted implants were the main reasons of this complication. Although wrong diagnosis was made initially which caused the failure and migration of the implants

The type of the dental implant is also a reason for this undesirable situation. Bone level implants might be disadvantageous when compared to tissue level implants. In literature, generally, bone level implants were used in reported cases of migrated dental implants into the maxillary sinus. ${ }^{2,8}$ In this present case report, bone level dental implants were used similar to the literature.

The management of the displaced dental implants into maxillary sinus is still on debate. Most of the authors recommended Caldwell-Luc procedure to overcome this complication but in recent days endoscopic approaches were reported. Chiapasco et $\mathrm{al}^{12}$ retrospectively evaluated paranasal sinus complications following displacement of oral implants in the maxillary sinus in 27 patients. They treated the patients with functional endoscopic sinus surgery (FESS), intraoral approach to the sinus, or FESS associated with an intraoral approach. They demonstrated that a rational option of surgical procedure for the treatment of complications concerning the paranasal sinuses secondary to the displacement of implants in the maxillary sinuses showed reliable results. In other case reports, Lubbe et $\mathrm{al}^{13}$ and Kitamura ${ }^{14}$ presented cases of migrated dental implants into the maxillary sinus and treatment of this situation with transnasal endoscopy. They claimed that endoscopic removal of dental implants and other foreign bodies within the maxillary sinus was a safe and minimally invasive procedure compared to the classic Caldwell-Luc procedure. In our cases, Caldwell-Luc surgery was used to remove the migrated implants. The major advantage of this method was the direct visualization of the maxillary sinus. However, endoscopic assisted surgical technique could be used in the management of this situation. 
Atatürk Üniv. Diş Hek. Fak. Derg.

J Dent Fac Atatürk Uni

Cilt:24, Sayı:1, Yıl: 2014, Sayfa: 93-97

In conlusion, dental implant procedures simultaneously with sinus augmentation must be planned carefully in order to optimize results in posterior maxilla. In cases of migrated implants into the sinus cavity, failed implants must be removed immediately. Caldwell-Luc surgery is a well defined method to manage this complication.

\section{REFERENCES}

1. Ungor C. Radiologic evaluation of putty versus powder form of demineralized bone matrix in sinus floor elevation. J Oral Implantol 2012;38:337-43.

2. Galindo-Moreno P, Padial-Molina M, Avila G, Rios HF, Hernández-Cortés $P$, Wang HL.Complications associated with implant migration into the maxillary sinus cavity. Clin Oral Implants Res. 2012;23:1152-60.

3. Yavuz MS, Aras MH, Uzun İH. Mini dental implant in the maxillary aesthetic region. J Dent Fac Ataturk Uni 2008;18:66-9.

4. Dimitriou C, Karavelis A, Triardis K. Foreign body in the sphenoid sinus. J Cranio-Max-Fac Surg 1992: 20: 228-9.

5. Haben CM, Balys R, Frenkiel S. Dental implant migration into the ethmoid sinus. J Otolaryngol 2003; 32:342-4

6. lida S, Tanaka N, Kogo M, Matsuya T. Migration of a dental implant into the maxillary sinus. Int. J. Oral Maxillofac Surg. 2000; 29:358-9.

7. Cascone P, Ungari C, Filiaci F, Gabriele G, Ramieri V. A dental implant in the anterior cranial fossa. Int J Oral Maxillofac Surg 2010;39:92-3.

8. González-García A, González-García J, Diniz-Freitas M, García-García A, Bullón P. Accidental displacement and migration of endosseous implants into adjacent craniofacial structures: a review and update. Med Oral Patol Oral Cir Bucal 2012;17:769-74.

9. Galindo P, Sanchez-Fernandez E, Avila G. Migration of implants into the maxillary sinus: Two clinical cases. Int J Oral Maxillofacial Implants 2005;20:291-5.

10. Regev E, Smith RA, Perrott DH. Maxillary sinus complications related to endosseous implants. Int J Oral Maxillofac Implants 1995;10:451-61.

11.Raghoebar GM, Vissink A. Treatment for an endosseous implant migrated into the maxillary
ÜNGÖR, ATASOY, ÇİZMECİ ŞENEL

sinus not causing maxillary sinusitis: case report. Int J Oral Maxillofac Implants 2003;18:745-9.

12. Chiapasco M, Felisati G, Maccari A, Borloni R, Gatti $F$, Di Leo $F$. The management of complications following displacement of oral implants in the paranasal sinuses: a multicenter clinical report and proposed treatment protocols. Int J Oral Maxillofac Surg. 2009; 38:1273-8.

13. Lubbe $D E$, Aniruth $S$, Peck T, Liebenberg $S$. Endoscopic transnasal removal of migrated dental implants. Br Dent J. 2008;204:435-6.

14. Kitamura A. Removal of a migrated dental implant from a maxillary sinus by transnasal endoscopy. $\mathrm{Br}$ J Oral Maxillofac Surg 2007;45:410-1.

\section{Yazışma Adresi}

Dr. Cem ÜNGÖR

Karadeniz Technical University

Faculty of Dentistry

Department of Oral and Maxillofacial Surgery, Trabzon, TURKEY

Tel 00905322403191

Fax 00904623253017

e-mail cem_ungor@yahoo.com 